\title{
A short history of Lagenaria siceraria (bottle gourd) in the Roman provinces: morphotypes and archaeogenetics
}

\author{
Angela Schlumbaum • Patricia Vandorpe
}

Received: 27 June 2011 / Accepted: 10 December 2011/Published online: 27 December 2011

(C) Springer-Verlag 2011

\begin{abstract}
Lagenaria siceraria (Molina) Standl. (bottle gourd) is pantropic and displays large variation in fruit and seed shape. Two subspecies are currently recognized: the African L. siceraria ssp. siceraria and the Asian L. siceraria ssp. asiatica. The Asian type of bottle gourd belongs to the earliest domesticated plants in the Americas. In Europe, bottle gourd only appears with some frequency from the Roman period onwards. The paper is the study of ancient DNA (aDNA) and seed morphology of one almost complete bottle gourd fruit from the Roman site of Oedenburg/Biesheim-Kunheim, France (1st century A.D.), and from individual seed finds from the Roman vicus of PetinescaVorderberg, Switzerland (3rd century A.D.), both recovered from waterlogged layers. Width and length measurements of seeds show large variation. Based on the index of width to length, seeds from both sites differ significantly ( $p<0.0001$ Mann-Whitney) suggesting that there were different variants present north of the Alps. Genetically, the bottle gourd fruit from Roman Oedenburg/Biesheim-Kunheim and one commercial cultivar L. siceraria cv. 'Herkuleskeule' are of Asian origin as identified by three Asian and African specific chloroplast markers. These results support an early and longlasting presence of the Asian type of domestic bottle gourd in
\end{abstract}

Communicated by F. Bittmann.

Electronic supplementary material The online version of this article (doi:10.1007/s00334-011-0343-x) contains supplementary material, which is available to authorized users.

A. Schlumbaum · P. Vandorpe $(\bowtie)$

Institute of Prehistory and Archaeological Science,

University of Basel, Spalenring 145, 4055 Basel, Switzerland

e-mail: patricia.vandorpe@unibas.ch

A. Schlumbaum

e-mail: angela.schlumbaum@unibas.ch
Europe. No chloroplast markers were found in the seeds from Petinesca-Vorderberg. However preserved nuclear high copy 5.8S rDNA fragments correctly matched to Cucurbitaceae, further supporting the evidence for preservation of DNA in waterlogged plant remains.

Keywords Archaeobotany · Ancient DNA . Morphology · Origin · Chloroplast DNA

\section{Introduction}

Lagenaria siceraria (Molina) Standl. (bottle gourd) is a white flowered, monoecious annual belonging to the Cucurbitaceae family. It has a pantropical distribution with regional economic importance and is used as a vegetable, container, musical instrument or float and its seeds for oil. It also has medicinal properties, which are valued in traditional medicine (Robinson and Decker-Walters 1997; Lorey and Reinhard 2002; Koffi et al. 2009; Shah et al. 2010).

Based on morphological characteristics including seed shape, Kobiakova (1930) early on recognized two subspecies of bottle gourd: L. vulgaris ssp. asiatica and $L$. vulgaris ssp. africana. Her work is still used in archaeobotanical research. In 1973, Heiser discussed the morphological variation within bottle gourd starting from the characteristics described by Kobiakova (1930). He redefined the subspecies as L. siceraria ssp. siceraria and $L$. siceraria ssp. asiatica (Heiser 1973). Recent studies of modern landraces of bottle gourd, however, reveal that their fruit and seed shape can be extremely variable (e.g. Morimoto et al. 2005; Achigan Dako et al. 2008; Yetisir et al. 2008) and might not warrant two subspecies (Fuller et al. 2010). 
Bottle gourd probably came originally from Africa. An indigenous wild population with brittle fruit rind was only recently discovered in Zimbabwe (Decker-Walters et al. 2004). The reconstruction of the origins and subsequent dispersal of bottle gourd is complex. It is most likely masked by recent cross-breeding and commercial cultivation (Decker-Walters et al. 2001; Clarke et al. 2006). Nonbitterness (Erickson et al. 2005; Morimoto et al. 2005) and thick fruit exocarps are considered to be domestication traits; the latter makes the fruit suitable for use as containers. Two domestication events, one in Asia and a later one in Africa appear to be possible (Erickson et al. 2005). Archaeological finds of early Holocene bottle gourds support an early cultivation in Asia (Fuller et al. 2010). Ancient DNA (aDNA) analyses of three chloroplast markers, distinguishing between modern Asian and African landraces, show that domestic bottle gourd reached the Americas with Palaeo-Indians via Asia about 10,000 years ago. It did not disperse via ocean currents and represents one of the first domesticated plants with a worldwide distribution. In America these Asian type bottle gourds were only much later replaced by the African types (Erickson et al. 2005; Clarke et al. 2006).This study clearly reflects the potential of aDNA to shed light on past human selection as well as to detect signatures lost in modern individuals.

In Europe, finds of bottle gourd emerge much later. Apart from a single seed from an Iron Age site in northern Italy (Rottoli and Pessina 2007), it is only during the Roman period that they appear with any frequency in archaeological sites. Romanization of areas north of the Alps is associated with the introduction of previously unknown crops, including bottle gourd, into the colonized areas (Jacomet et al. 2002; Bakels and Jacomet 2003). Predominantly seeds, but also rind fragments and almost complete fruits of bottle gourd are reported from sites covering a large geographical area from France, Germany, Switzerland and Italy to Egypt (Table 1; Fig. 1). So far no bottle gourd remains are known from Greece or the Iberian Peninsula (T. Theodoropoulou and F. Antolin pers. comm.). With the exception of desiccated finds from Egypt, European bottle gourd remains are preserved through waterlogging or mineralization. The rarity of bottle gourd remains in the archaeological record may be due to different conditions of preservation. Some sites yielded very few remains, whereas others much more (Table 1). The site of Oedenburg/Biesheim-Kunheim in the upper Rhine valley in Alsace, France, produced the largest archaeological assemblage of bottle gourd remains known for the Roman period so far (Reddé et al. 2005; Vandorpe and Jacomet in press). Whether or not these remains of bottle gourd derive from local cultivation or long-distance trade remains unclear. Local cultivation would have been easily possible, as today's farmers and an experiment in the
Botanical Garden of the University of Basel $(\mathrm{CH})$ demonstrate (Jacomet and Brombacher 2009; Vandorpe and Jacomet in press). Archaeological finds of bottle gourd from medieval sites are less abundant, see Houten (NL) Kooistra and Hessing (1988), Oberflacht (D) Bertsch (1927), Trossingen (D) Rösch and Fischer (2004), Colletière (F) Lundström-Baudais et al. (1993) and Zama (2000), as well as other unpublished records.

Besides the archaeological sources, bottle gourds are mentioned in the ancient literature, in particular in three 1st century A.D. texts: De Materia Medica by Dioscorides (Beck 2005), De Re Rustica by Columella (Ash 1941; Forster and Heffner 1955) and Historia Naturalis by Pliny the Elder (Rackham 1950; Jones 1951), and also in compilations of the Jewish laws of the 1st to 2nd century A.D., Mishna and Tosefta (see review in Janick et al. 2007; Paris and Janick 2008). The ancient authors distinguish between the narrow, long-fruited cultivars that were used as vegetables and the broad, short-fruited cultivars that were used for a variety of purposes such as containers or as swimming aids. In addition, they are illustrated for example in paintings, mosaics and sculptures from that period (Köhler 2002; Janick et al. 2007; Paris and Janick 2008).

From the medieval period, paintings of bottle gourds are known from 15th century books and in numerous 16th century paintings and tapestries including those of the Villa Farnesina (Rome, Italy) decorated between 1515 and 1518 (Janick and Paris 2006; Paris et al. 2006, 2009) where three morphological variants have been detected, large bottleshaped, small bottle-shaped and elongate ones (Janick and Paris 2006).

Today people rediscover "lost" vegetables such as bottle gourds in Europe and bottle gourd was elected "vegetable of the year 2002" in Germany (Lorey and Reinhard 2002).

In the present study, aDNA and morphotypes of bottle gourd remains from two Roman sites north of the Alps, Oedenburg/Biesheim-Kunheim (F) and Petinesca-Vorderberg $(\mathrm{CH})$ are analysed in order to identify their genetic origin. Results have been compared and combined with morphometric data from other available modern and archaeological data.

\section{Materials and methods}

Material

The archaeological samples originate from two key sites of the Roman period north of the Alps.

From the civil settlement of Oedenburg/BiesheimKunheim (Département Haut-Rhin, France), referred to 


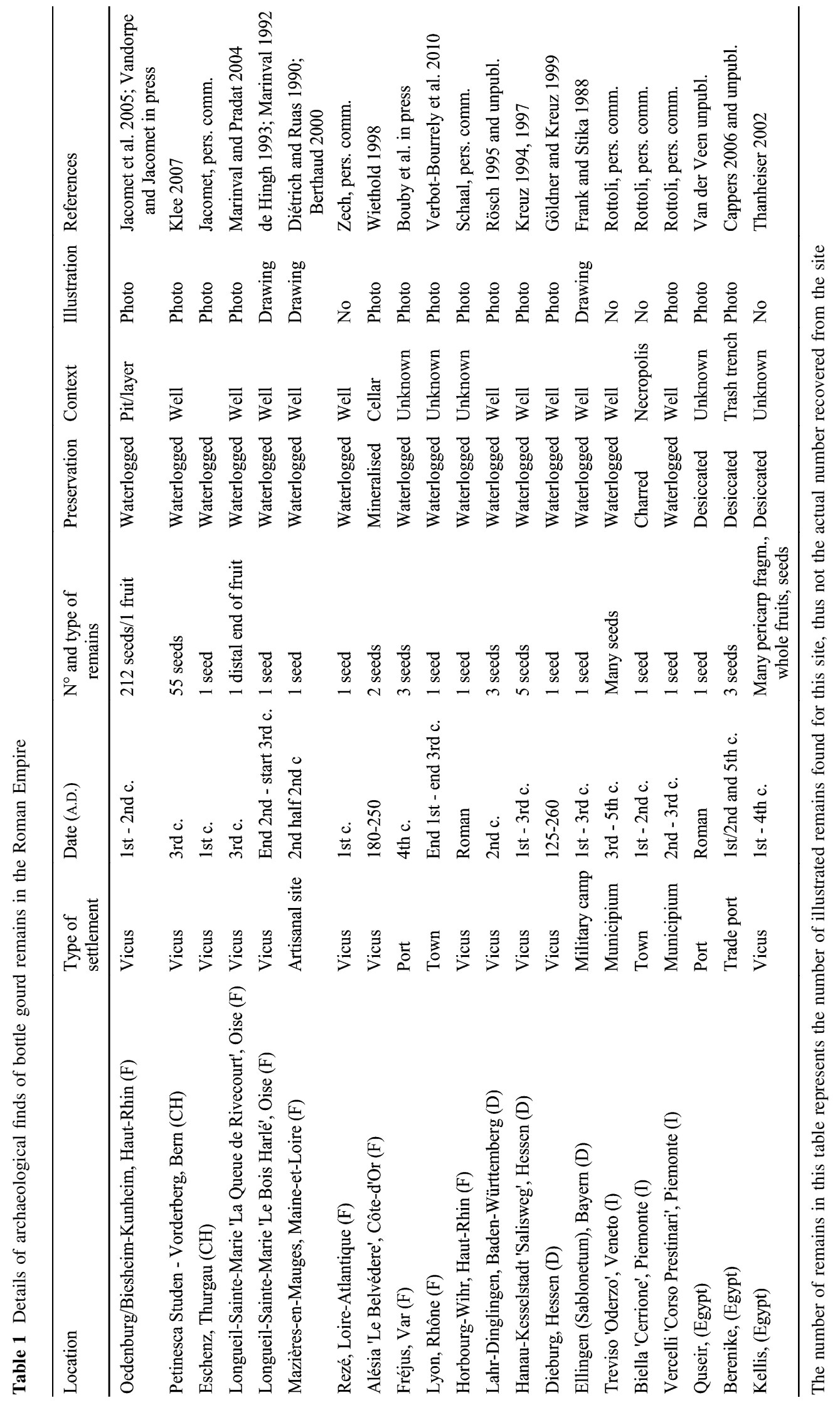




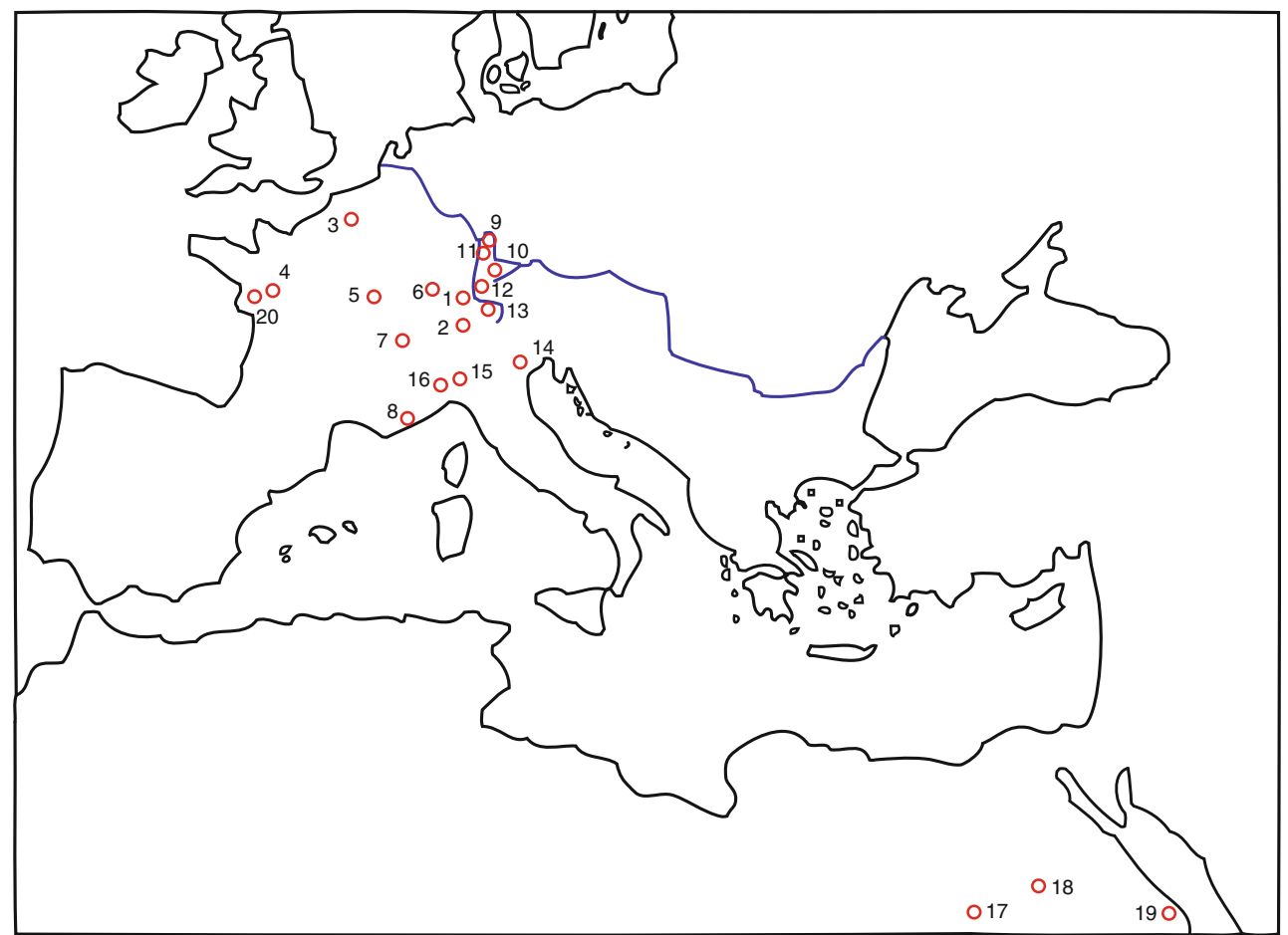

Fig. 1 Distribution map of all Roman finds of bottle gourd as listed in Table 1. 1, BK (F); 2, PET (CH); 3, Longeuil-Ste-Marie (F); 4, Mazières-en-Mauge (F); 5, Alésia (F); 6, Horbourg-Wihr (F); 7, Lyon (F); 8, Fréjus (F); 9, Dieburg (D); 10, Ellingen (D); 11, Hanau-

below as BK, an almost complete bottle gourd fruit containing 212 seeds was found within a waterlogged layer of waste (BK09-03-74, excavated in 2003, Figs. 2 and 3) (Vandorpe and Jacomet in press). The shape of the fruit could not be identified as the bottom part was missing. It is probably of the broad short-fruited type. The gourd rind fragments have been ${ }^{14} \mathrm{C}$ dated between 40 cal. B.C.-cal. A.D. 80 (95.4\% probability; ETH-38301: $1970 \pm 25$ в.P.) (Bronk Ramsey 2001; Reimer et al. 2004). After excavation the fruit was stored at $6^{\circ} \mathrm{C}$ in its original wet sediment.

From the vicus of Petinesca-Vorderberg (Canton Bern, Switzerland), referred to below as PET: 55, waterlogged bottle gourd seeds were found within the fill of a well (well 1, excavated between 1985 and 1990, Fig. 3) (Klee 2007). The layer is dated typologically by pottery to the middle of the 3rd century A.D. (Zwahlen et al. 2007). After excavation, the bottle gourd seeds were dried and stored at room temperature.

For comparison, seeds of modern commercial bottle gourds were studied. They belong to one fruit of a cultivar known as "Speckled Swan" from a local market in southern Germany (LOC) (Fig. 3). The fruit shape is container-like and enclosed 201 seeds. Besides, 18 seeds from the cultivar L. siceraria cv. Herkuleskeule (Sperli Samen, Germany) (HERK) have been analysed.
Kesselstadt (D); 12, Lahr (D); 13, Eschenz (CH); 14, Oderzo (I); 15, Cerrione (I); 16, Vercelli (I); 17, Kellis (ET); 18, Quseri (ET); 19, Berenike (ET); 20, Rezé (F)

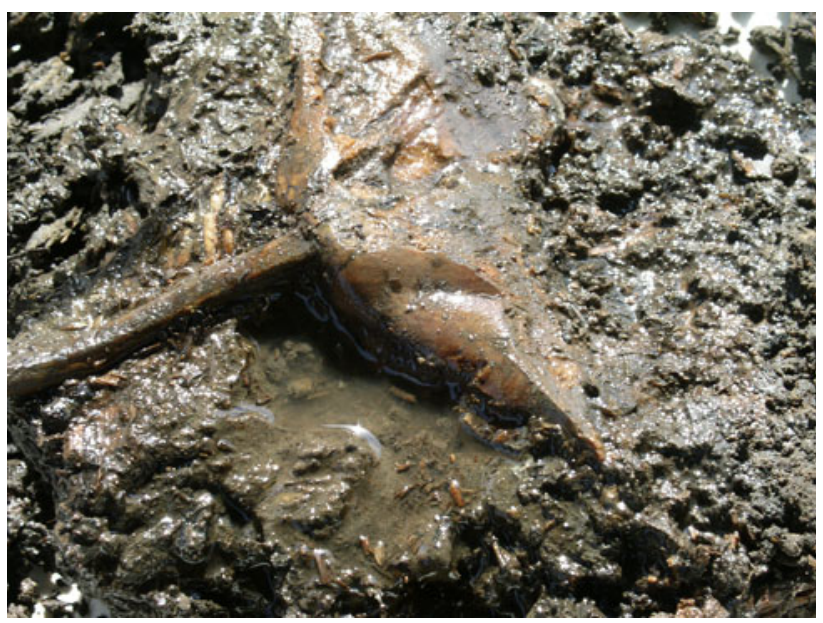

Fig. 2 Nearly complete bottle gourd fruit from Oedenburg/Biesheim-Kunheim dated to the 1st century A.D.; photo, IPNA Basel

For a broader context we explored published and unpublished photographs and drawings of bottle gourd seeds from modern landraces (Heiser 1973; Zoro Bi et al. 2003; DeckerWalters et al. 2004; Morimoto et al. 2005; Achigan Dako et al. 2008; Yetisir et al. 2008) as well as from archaeological samples from a large geographical area within the Roman Empire (Table 1; Fig. 1). The seeds from the different samples are referred to below as seed 'populations'. 

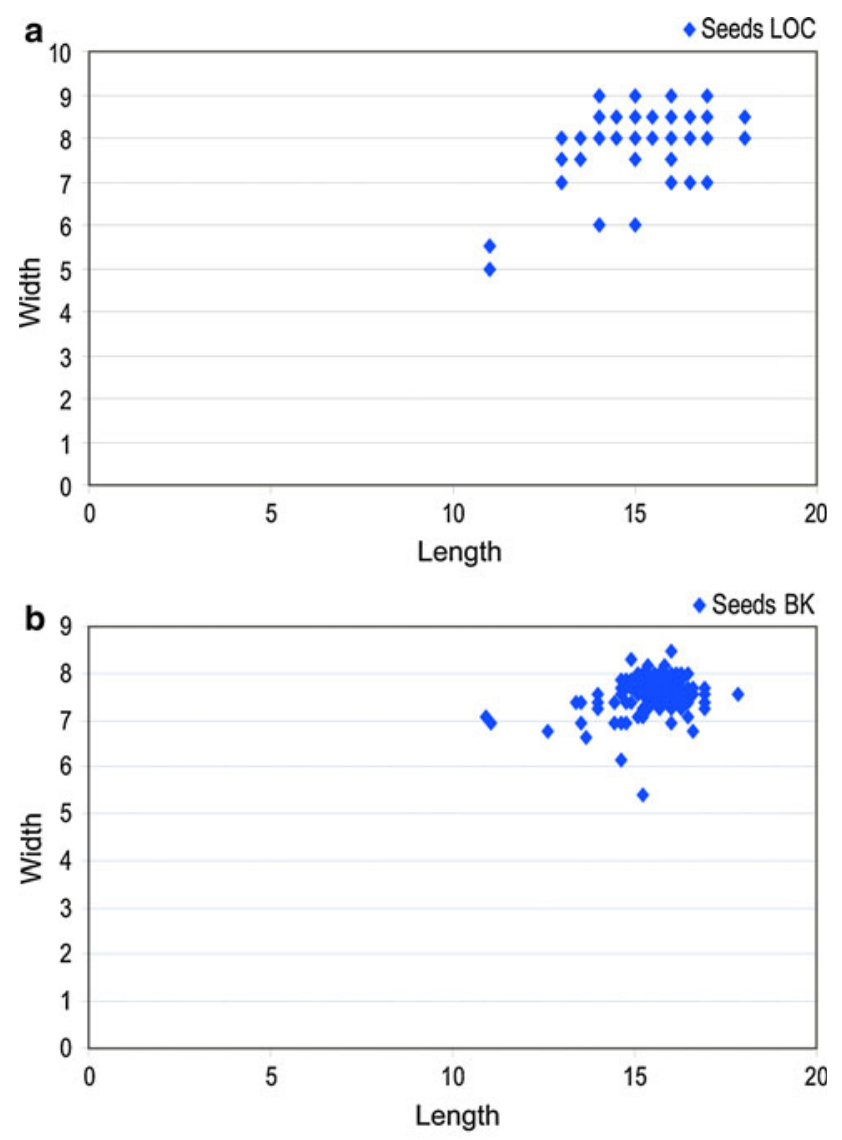

C

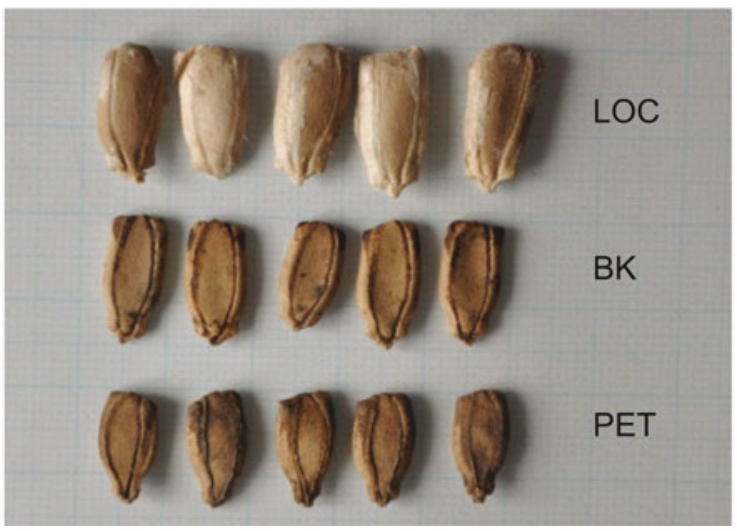

Fig. 3 a, b Graphs showing width and length measurements in $\mathrm{mm}$ of all seeds from LOC and BK; c waterlogged seeds from BK, waterlogged seeds from PET (dried after excavation), modern seeds from LOC

\section{Methods}

Ancient DNA extraction, PCR amplification, cloning and sequencing

Four subsamples (LAG 15-LAG 18) of ca. $1 \mathrm{~cm}^{2}$ from the bottle gourd exocarp from Oedenburg/Biesheim-Kunheim and four seeds (PET 26, PET 27, PET 31, PET 32) from Petinesca-Vorderberg were pulverized with a mortar and pestle in liquid nitrogen without external treatment.
DNA was extracted using Plant DNA Easy Kit (Qiagen, Hilden, Germany) according to the manufacturer's instructions, with slight modifications. The extracts were further purified by washing twice with $\mathrm{ddH}_{2} \mathrm{O}$ (Vaudaux Eppendorf, molecular biology grade (Allschwil, $\mathrm{CH}$ ), through Microccon $30 \mathrm{kD}$ columns (Millipore, $\mathrm{CH}$ ). Two extraction blanks for four samples were prepared accordingly. 100-200 $\mu \mathrm{l}$ were recovered. Extracts were diluted ten and hundredfold to overcome inhibition.

PCR was carried out in $25 \mu$ reactions in an Eppendorf Mastercycler (Vaudaux Eppendorf, Allschwil, $\mathrm{CH}$ ), using $3 \mu \mathrm{l}$ of template DNA, $0.2 \mu \mathrm{M}$ of each primer, $2.5 \mathrm{mM}$ $\mathrm{MgCl}_{2}, 125 \mu \mathrm{M}$ dNTPs and 2.5 U AmpliTaq Gold (Applied BioSystems, Rotkreuz, $\mathrm{CH}$ ). The three chloroplast primers diagnostic for either an Asian or African origin within the trnC-trnD (indel 1, SNP A/G) and trnS-trnG (indel 2) intergenic regions described by Erickson et al. (2005) were used. The Asian type is defined by In-A-Del, the African type by Del-G-In. In seeds from Petinesca, $70 \mathrm{bp}$ of the nuclear 5.8 S rDNA was additionally amplified (Lag ITS F: 5'-CAG GAT CCC GCG AAC CAC CG-3'; Lag ITS R: 5'AGA CGT GCC CTC GGC CAG AA-3'). The cycling conditions were an initial activation of $11 \mathrm{~min}$ at $95^{\circ} \mathrm{C}$, followed by 70 cycles of $1 \min 95^{\circ} \mathrm{C}$, annealing of $1 \mathrm{~min}$ at $50^{\circ} \mathrm{C}$ for both indell and SNP, $47^{\circ} \mathrm{C}$ for indel 2 and $60^{\circ} \mathrm{C}$ for ITS, elongation for $1 \mathrm{~min}$ at $72^{\circ} \mathrm{C}$ with $5 \mathrm{~min}$ at $72^{\circ} \mathrm{C}$ final elongation. Two PCR blanks were included in every run. PCR products were visualized on $3 \%$ NuSieve agarose. PCR products were gel-eluted using MinElute Gel Extraction Kit (Qiagen, CH), purified with Qiaquick PCR Purification KIT (Qiagen) or directly used for cloning with TOPO TA cloning Kit (Invitrogen, LuBioScience, $\mathrm{CH}$ ). Positive clones were sequenced by Microsynth, Balgach, $\mathrm{CH}$.

Commercial L. siceraria cv. Herkuleskeule was typed for indel 1 using Phire Plant Direct PCR Kit (BioConcept, Allschwil, $\mathrm{CH}$ ) and $0.5 \mathrm{~mm}$ disks of young leaves. PCR products were purified from $3 \%$ NuSieve agarose gels with a MinElute gel extraction Kit (Qiagen, $\mathrm{CH}$ ) and directly sequenced in both directions as above. The sequences were deposited with Genbank (JN232920-23). Sequences were aligned with BioEdit (http://www.mbio.ncsu.edu/bioedit/ bioedit.html).

\section{Precautions and authenticity}

For authenticity procedures we followed the suggestions of Gilbert et al. (2005). In particular, extraction and PCR setup steps were performed in physically separated rooms dedicated to aDNA work. Surfaces were bleached and UV irradiated, consumables and $\mathrm{ddH}_{2} \mathrm{O}$ (Vaudaux Eppendorf, molecular biology grade Allschwil, $\mathrm{CH}$ ) were UV irradiated; for details see Pollmann et al. (2005). Because two markers are indels of $5 \mathrm{bp}$, post mortem degradation of 
individual bases was not an issue, and 2-6 clones for each sub-sample and primer pair were sequenced. Geographical assignment was unambiguous. Controls were always negative. In case of BK, authenticity is confirmed by the successful typing of ITS 1 in apple seeds from the same layer (Schlumbaum et al. 2011).

\section{Seed morphometry}

Seed lengths and widths were measured either directly from seeds or from photographs using a ruler and an eyepiece graticule. For comparison and to balance the differences, which are due to the various types of seed populations (waterlogged condition, wet preserved, waterlogged preservation, dry preserved, photograph), the index (I) of width/length was calculated. We observed that the index did not change significantly with a trend to be lower (more "Asian") after drying wet preserved seeds from BK. Heiser (1973) suggested this index as part of a set of morphological traits for the characterization of modern bottle gourd cultivars: the ssp. siceraria type seeds are "generally less than twice as long as broad, with or without corky wings, longitudinally lined or smooth, lines seldom pubescent, with or without ears, generally dark in color"; the ssp. asiatica type of seeds are "generally more than twice as long as broad, without corky wings, longitudinally lined, lines sometimes pubescent, usually eared, gray, brown or white in color" (Heiser 1973, p. 124). He notes the large variation found in African accessions (Heiser 1989). We have used the index strictly in our argument by subjectively defining $I<0.5$ as Asian and $I>0.5$ as African.

To visualize indices from the different populations, a scatter plot was produced with SPSS V.19. To test for similarity or dissimilarity between the populations of BK, PET and the two commercial cultivars LOC and HERK, a non-parametric Mann-Whitney $U$ test was performed using XLSTAT 2010.6.04. The significance level was set at 5\%, and the boxplot was calculated with PAST (http://folk. uio.no/ohammer/past/).

\section{Results}

aDNA analysis

The chloroplast markers described by Erickson et al. (2005) distinguish between Asian and African landraces at three loci unequivocally: one indel and a SNP A/G within trnC-trnD, and one indel within the trnS-trnG intergenic region.

All three diagnostic chloroplast markers were repeatedly amplified from four exocarp extracts from a 1st century A.D. bottle gourd BK (1:10 dilution). Sequences obtained from 46 clones consistently exhibit the pattern In-A-Del established for Asian bottle gourds (Fig. 4, ESM Fig. 1, ESM Fig. 2; Erickson et al. 2005). This confirms the robustness and validity of the markers for European archaeological bottle gourd rind fragments. Amplification success differed in the four subsamples ranging from two



Fig. 4 Sequence alignment of partial chloroplast $t r n \mathrm{C}-\operatorname{trn} \mathrm{D}$ (indel 1) from Roman L. siceraria rind fragments from Oedenburg/BiesheimKunheim (BK) in comparison with $L$. siceraria from the Americas (Erickson et al. 2005) and modern L. siceraria cv. Herkuleskeule,

Citrullus lanatus and Cucumis sativus. Numbering of nucleotide positions is according to AY508002, dots represent identical nucleotides, dashes indicate missing nucleotides 
positive reactions in LAG 17 to seven in LAG 18 out of a total of nine PCR runs, which might indicate the presence of spurious inhibitors, despite dilution or differential preservation within the rind.

In the four individual seeds from PET, the chloroplast markers could not be consistently amplified. Fragments of nuclear 5.8S rDNA gene were amplified repeatedly in one extract of seed PET 32 and the sequences of clones are identical to Cucurbitaceae (ESM Fig. 3), confirming the preservation of original nuclear DNA. As with the rind subsamples, amplification was successful in three out of seven PCR runs.

The commercial L. siceraria $\mathrm{cv}$. Herkuleskeule has the insertion in the trnC-trnD intergenic region, and belongs to the Asian type of bottle gourd (Fig. 4).

Concerning the trnC-trnD intergenic region, both modern HERK and Roman BK are identical to each other and share the haplotype with previously published sequences from the Americas (Fig. 4; Erickson et al. 2005). Roman BK also shares haplotypes within the trnS-trnG intergenic region (ESM Fig. 1).

Seed measurements and indices from Roman seeds and two cultivars

Based on the drawings of seeds by Kobiakova (1930, p. 488, Fig. 15), the bottle gourd seeds from BK and PET correspond to the ssp. asiatica type of bottle gourd: they do mostly possess the prominent ears and pubescent lines and are triangular.

Measurements of more than 200 seeds, all from one fruit, from Roman BK and from modern LOC demonstrate an equivalent range in length and width (Fig. 2a).

Based on the calculation of indices $(I)$, the BK waterlogged seeds $(N=212)$ vary between 0.354 and 0.648 , with a mean value of 0.488 (Fig. 5, ESM Table 1). The variability in the index observed in the waterlogged preserved but dried seeds $(N=55)$ from PET is lower (Fig. 5), the indices range between 0.462 and 0.617 , and the mean value is 0.54 . According to the Mann-Whitney $U$ test, the indices of the seed populations of BK and PET are significantly different $(p<0.0001)$ (ESM Table 2$)$.

For the seeds recovered from LOC $(N=201)$, the container-like cultivar "Speckled Swan", the index ranges from 0.4 to 0.643 with a mean value of 0.522 ; compared to the seeds from BK, the intra-individual variation is similar. For the commercial seeds of HERK $(N=18)$, a minimum index of 0.367 , a maximum index of 0.538 and a mean value of 0.432 was calculated (Fig. 5). According to the Mann-Whitney $U$ test, both modern cultivars are significantly different to each other as well as to the archaeological samples from both key sites $(p<0.0001)$ (ESM Table 2).

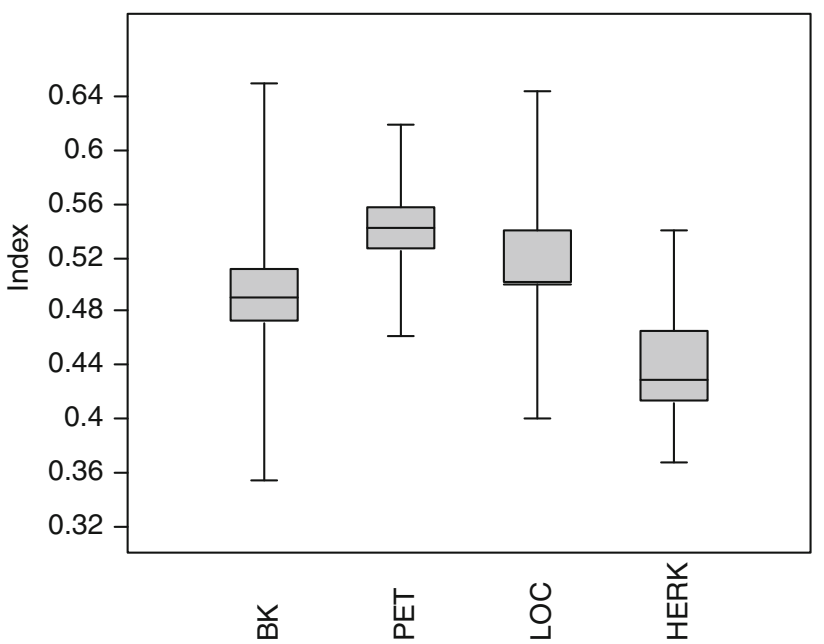

Fig. 5 Boxplot showing the distribution of length/width indices calculated from bottle gourd seeds from the two Roman sites Oedenburg/Biesheim-Kunheim, F (BK) and Petinesca-Vorderberg, $\mathrm{CH}$ (PET) in comparison with two cultivars $L$. siceraria $\mathrm{cv}$. Speckled Swan (LOC) and cv. Herkuleskeule (HERK)

Relationship between archaeological and modern Lagenaria seed morphotypes

In order to put our data into a broader context, we calculated indices from measurements of published seed photographs from landraces of different geographical regions as well as from all available archaeological seeds listed in Table 1. The largest range of indices was found in the African population published by Heiser (1973), and all other values fall more or less within this range (Fig. 6).

Applying the mean indices of the four seed populations ( $I<0.5$ typical for Asian populations), it appears that the seeds from Roman BK and modern HERK belong to the Asian type of bottle gourd. For both BK and HERK the Asian origin is confirmed by genetics (see above). However, looking at the individual seeds, then $29 \%$ of BK seeds have $I>0.5$, which is not in accordance with an Asian origin. Likewise, based on the mean index, seeds from Roman PET and modern LOC could be attributed to the African type of bottle gourds (I mean $>0.5$ ). For PET and LOC, no genetic evidence corroborates the assumption. Similarly to BK, $11 \%$ of PET seeds have an index $<0.5$, indicating the Asian type. Both PET and LOC have the morphological traits corresponding to the Asian origin as defined by Kobiakova (see above).

Among the other Roman archaeological finds, the majority of indices are $<0.5$ (Fig. 6). There are some exceptions with an index $>0.5$ from Mazières en Mauge (F), Alésia (F) and Horbourg-Wihr (F) (Table 1; Fig. 6). Nevertheless, considering the seed characteristics defined 


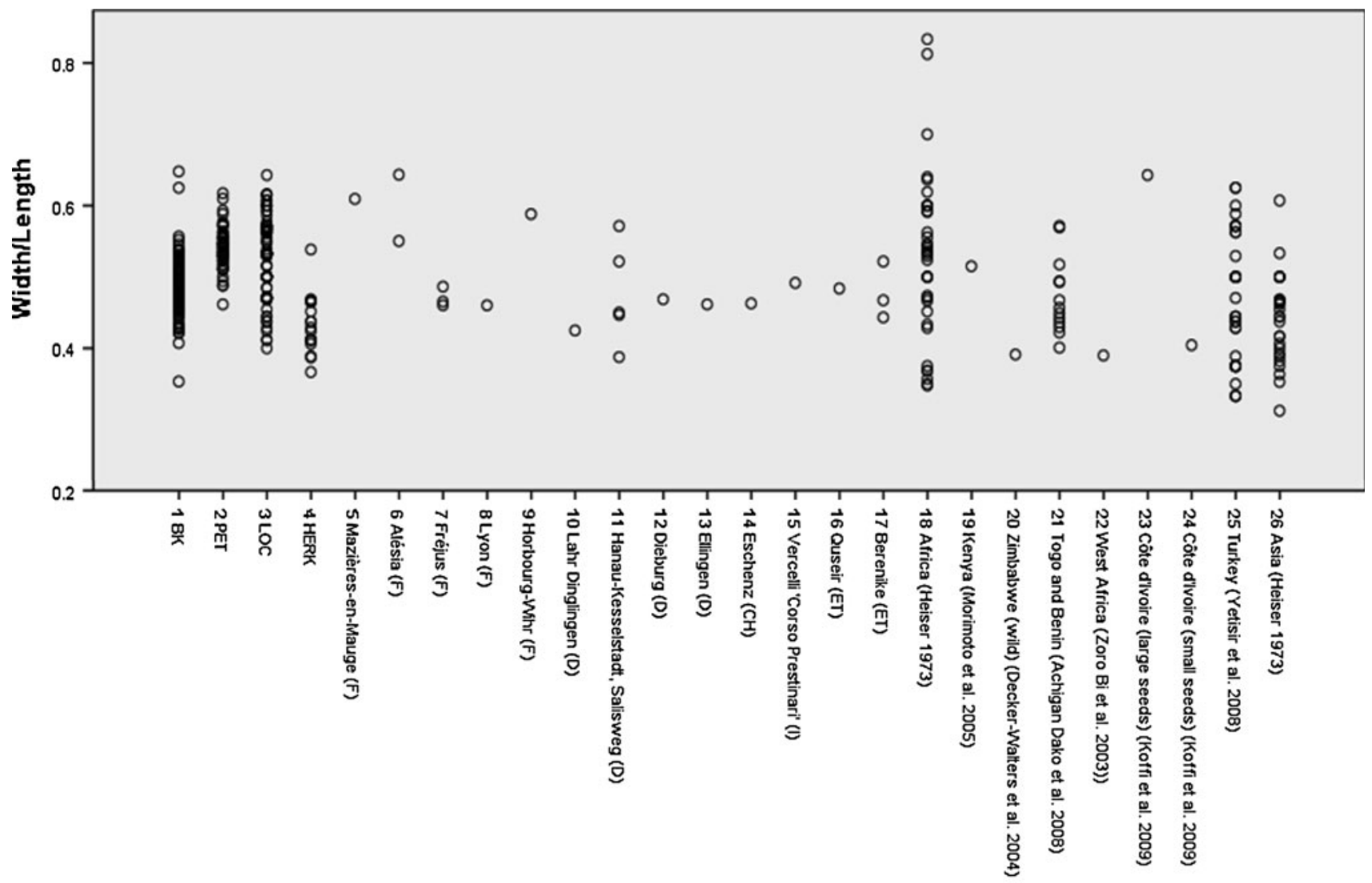

Name of site

Fig. 6 Scatter plot of seed indices (width/length) of both Roman and modern populations as listed in ESM Table 1

by Kobiakova (1930) once more, all archaeological finds can be assigned to the Asian type of bottle gourd.

\section{Discussion}

The combined application of aDNA technology and morphometry, in particular geometric morphometrics, to archaeobotanical samples has great potential to trace the history of cultivated plants and the diversification of cultivars through time in relation to cultural periods. First attempts are in progress for grapevine (Alexandre-Bidon et al. 2010; Terral et al. 2010). Hence, our results on $L$. siceraria contribute to this new approach, though we only use simple width/length indices.

Our results from the fruit from Oedenburg/BiesheimKunheim (F) provide unequivocal evidence that the Asian type was introduced into the northern Alpine area in Roman times. It also demonstrates the long-lasting and worldwide geographical distribution of the Asian chlorotype, since the earliest finds in the Americas date to $8685 \pm 60$ cal. в.P. (Erickson et al. 2005). The origin of the bottle gourds which were brought to the northern Alpine region in the Roman period remains unclear as the genetic origin does not necessarily reflect the region of import. It is however possible that the Romans imported them from Asia (Bakels and Jacomet 2003). This was already stated by several ancient authors (Köhler 2002).

Today in Europe, cultivars of the Asian chlorotype are still grown, as seen with $L$. siceraria cv. Herkuleskeule. In contrast, in the Americas the Asian types appear to have been replaced by African types in the last few centuries (Erickson et al. 2005).

For the 3rd century A.D. seeds from Petinesca-Vorderberg, the genetic analysis of the geographical chloroplast markers failed, most probably due to the fact that all archaeological seed finds consist of a lignified seed coat (testa) only. The degradation of the embryo containing the chloroplast DNA poses a frequent problem of typing cpDNA in archaeological seeds (Pollmann et al. 2005; Schlumbaum et al. 2008, 2011). In the PET seeds the nuclear ITS region was however preserved, which opens up future possibilities to study potential hybridization and origin with nuclear markers (Clarke et al. 2006). The results of the genetic analysis confirm the potential of waterlogged preserved plant material for aDNA analysis 
(Schlumbaum et al. 2008) and the robustness of the primer for other geographic regions by Erickson et al. (2005).

Interestingly, in case of BK and HERK the genetic results correlate with the seed morphology (Kobiakova 1930): simple measurements and the calculation of a mean index points to an Asian origin in both seed populations. Whether this can be extended to other samples is yet to be confirmed, such as in the case of PET. In the absence of genetic data, the morphology of the PET seeds corresponds with Kobiakova's (1930) observations for the Asian type; their mean index however points to the African type.

More aspects arise from morphometry alone. One is that the Roman seed populations BK and PET differ significantly. A simple explanation is the presence of different varieties or landraces within a period of 200 years in the Swiss northern Alpine region and the Rhine valley. Yet for modern bottle gourd, the definition of modern landraces is notoriously difficult due to the large phenotypic variation in gourds. It seems that, if indeed groups were found, they would be defined by other characters than those of seeds (Morimoto et al. 2005; Achigan Dako et al. 2008). Another scenario would be local adaptations to the environment or the agricultural practices, including selection by humans. Selection on seed size, small and large, was observed in Côte d'Ivoire (Koffi et al. 2009). Both possibilities are discussed for modern Lagenaria landraces, so far without a final conclusion (Achigan Dako et al. 2008). Furthermore, the variation of seed index in both a modern and a Roman bottle gourd is similarly large, and this supports the thesis that human selection was not on seeds, but rather on fruit shape and other traits (Morimoto et al. 2005). With our dataset we cannot clarify these issues.

Within archaeobotanical research, in particular when only few seeds are available, assignments of origin are almost certainly not possible for several reasons: (a) the large range of seed length and width within even a single fruit, as seen in Roman BK and modern LOC (Fig. 3); (b) there are only few published data on seed morphology, above all from the African continent; (c) the likely hybrid types in recent landraces; and d) there are no studies that combine genetic data with morphometric data for bottle gourd seeds.

Future interdisciplinary investigations of archaeological bottle gourd remains using geometric morphometrics and archaeogenetics may contribute to the puzzling complexity observed in modern bottle gourd, and are crucial to understand the way this complexity has evolved through time.

Acknowledgments We are grateful to René Cappers, Laurent Bouby, Marijke van der Veen and Caroline Schaal for unpublished photographs of Lagenaria seeds. Thanks to Stefanie Jacomet, Renate Ebersbach and Christine Pümpin for valuable comments and thanks to Francesco Menotti for revising our English. The study was financed by Freiwillige Akademische Gesellschaft (FAG) Basel, $\mathrm{CH}$ and Emilia Guggenheim-Schnurr Stiftung, Basel, $\mathrm{CH}$.

\section{References}

Achigan Dako EG, Vodouhe SR, Sangare A (2008) Morphological characterization of cultivars of Lagenaria siceraria collected in Benin and Togo. Belg J Bot 141:21-38

Alexandre-Bidon D, Bouby L, Durand A, Ivorra S, Mane P, Piponnier F, Picq S, Puig C, Ouerfelli M, Ruas M-P, Schlumbaum A, Terral J-F (2010) Les Fruits-culture et consommation. Histoire et Images Medievales 33:18-38

Ash HB (ed, trans) (1941) Lucius Junius Moderatus Columella: on Agriculture I-IV. Harvard University Press, Cambridge, MA, pp $148-151$

Bakels C, Jacomet S (2003) Access to luxury foods in Central Europe during the Roman period: the archaeobotanical evidence. In: Van der Veen M (ed) Luxury foods, World Archaeology 34:542-557

Beck LY (ed, transl) (2005) Pedanius Dioscorides of Anazarbus: De Materia Medica. Olms-Weidmann, Hildesheim

Berthaud G (2000) Mazières-en-Mauges gallo-romain (Maine et Loire). Un quartier à vocation artisanale et domestique. ARDAAFAN, Angers

Bertsch K (1927) Die Obstreste aus den Alamannengräbern von Oberflacht. Ber Dt Bot Ges 45:23-30

Bouby L, Figueiral I, Schaal C (in press) Graines, fruits bois et charbons d'un espace horticole au cours de l'Antiquité et de l'Epoque moderne : analyse archéobotanique du site des « Thermes de Villeneuve », Fréjus (Var). In: Excoffon P (ed) Jardins et exploitations agricoles aux abords de Fréjus antique et moderne. La fouille préventive de VillaRomana (Fréjus, Var). Bibliothèque d'Archéologie Méditerranéenne et Africaine, Errance/CCJ, Paris, Aix-en-Provence

Bronk Ramsey C (2001) Development of the radiocarbon calibration program OxCal. Radiocarbon 43:1,029-1,058

Cappers R (2006) Roman food prints at Berenike. Archaeobotanical evidence of subsistence and trade in the Eastern Desert of Egypt. (Cotsen Monographs 55) (Berenike Reports 6) Cotsen Institute for Archaeology, Los Angeles

Clarke AC, Burtenshaw MK, McLenachan PA, Erickson DL, Penny D (2006) Reconstructing the origins and dispersal of the Polynesian bottle gourd (Lagenaria siceraria). Mol Biol Evol 23:893-900

De Hingh AE (1993) Bottle gourd seeds at Gallo-Roman Le Bois Harlé (Oise, France). Analecta Praehist Leidensia 26:93-97

Decker-Walters DS, Staub J, Lopez-Sesé A, Nakata E (2001) Diversity in landraces and cultivars of bottle gourd (Lagenaria siceraria; Cucurbitaceae) as assessed by random amplified polymorphic DNA. Gen Res Crop Evol 48:369-380

Decker-Walters DS, Wilkins-Ellert M, Chung S-M, Staub JE (2004) Discovery and genetic assessment of wild bottle gourd [Lagenaria siceraria (Mol.) Standley; Cucurbitaceae] from Zimbabwe. Econ Bot 58:501-508

Diétrich A, Ruas MP (1990) Des hommes et des plantes au IIe siècle à Mazières-en-Mauges. In: Berthaud G (ed) A la recherche de ses origines. Mazière-en-Mauges Maine-et-Loire de la préhistoire à l'époque romaine. Plaquette de l'exposition (décembre 1990). Association Maziéraise d'Archéologie, Direction des Antiquités Historiques des Pays de Loire, pp 27-32

Erickson DL, Smith BD, Clarke AC, Sandweiss DH, Tuross N (2005) An Asian origin for a 10,000-year-old domesticated plant in the Americas. Proc Natl Acad Sci 102:18,315-18,320 
Forster ES, Heffner EH (ed, transl) (1955) Lucius Junius Moderatus Columella: on Agriculture X-XII. Harvard University Press, Cambridge, pp 26-27, 40-43, 159-163

Frank K-S, Stika H-P (1988). Bearbeitung der makroskopischen Pflanzen und einiger Tierreste des Römerkastells Sablonetum (Ellingen bei Weissenburg in Bayern). (Materialhefte zur bayerischen Vorgeschichte Reihe A, 61) Laßleben, Kallmünz

Fuller DQ, Hosoya LA, Zheng Y, Qin L (2010) A contribution to the prehistory of domesticated bottle gourds in Asia: rind measurements from Jomon Japan and Neolithic Zhejiang, China. Econ Bot 64:260-265

Gilbert MTP, Bandelt H-J, Hofreiter M, Barnes I (2005) Assessing ancient DNA studies. Trends Ecol Evol 20:541-544

Göldner H, Kreuz A (1999) Begraben an einem stillen Ort: Botanische und archäologische Funde als neue Hinweise zum Leben im römische Dieburg. Denkmalpflege \& Kulturgeschichte 2:10-17

Heiser CB Jr (1973) Variation in the bottle gourd. In: Meggers BJ, Ayensu ES, Duckworth D (eds) Tropical forest ecosystems in Africa and South America: a comparative review. Smithonian Institution Press, Washington, pp 121-128

Heiser CB Jr (1989) The domestication of Cucurbitaceae: Cucurbita and Lagenaria. In: Harris DR, Hillman GC (eds) Foraging and farming. Unwin Hyman, London, pp 471-480

Jacomet S, Brombacher C (2009) Geschichte der Flora in der Regio Basiliensis seit 7500 Jahren: Ergebnisse von Untersuchungen pflanzlicher Makroreste aus archäologischen Ausgrabungen. Mitt Naturforsch Ges beider Basel 11:27-106

Jacomet S, Schibler J, Maise C, Wick L, Deschler-Erb S (2002) Mensch und Umwelt. In: Flutsch L, Niffeler U, Rossi F (eds) Römische Zeit. Verlag Schweizerische Gesellschaft für Ur- und Frühgeschichte, Basel, pp 21-40

Jacomet S, Schlumbaum A, Vandorpe P, Wick L (2005). Plantes indigènes, cultivées et importées. In: Reddé $\mathrm{M}$, Nuber HU, Jacomet S, Schibler J, Schucany C, Schwarz PA, Seitz G (eds) Oedenburg - une agglomération d'époque romaine sur le Rhin supérieur. Fouilles françaises, allemandes et suisses sur les communes de Biesheim et Kunheim (Haut-Rhin). Gallia 62:252-257

Janick J, Paris HS (2006) The Cucurbit images (1515-1518) of the Villa Farnesina, Rome. Ann Bot 97:165-176

Janick J, Paris H, Parrish D (2007) The Cucurbits of Mediterranean antiquity: identification of taxa from ancient images and descriptions. Ann Bot 100:1,441-1457

Jones WHS (ed, transl) (1951) Pliny, natural history, vol VI. Harvard University Press, Cambridge, pp 4-11

Klee M (2007) Archäobotanische Untersuchungen: Samen und Früchte. In: Zwahlen R et al (eds) Vicus Petinesca - Vorderberg: Die Ziehbrunnen. Archäologischer Dienst des Kantons Bern, Bern, pp 93-113

Kobiakova JA (1930) The bottle gourd. Bull Appl Bot Genet Plant Breed 23:475-520

Koffi KK, Anzara GK, Malice M, Dje Y, Bertin P, Baudoin JP, Zoro Bi IA (2009) Morphological and allozyme variation in a collection of Lagenaria siceraria (Molina)Standl. from Cote d'Ivoire. Biotechnologie Agronomie Societe et Environnement 13:257-270

Köhler J (2002) Der Flaschenkürbis bei Griechen und Römern. In: Hammer K, Gladis T, Hethke M (eds) Kürbis, Kiwano \& Co. vom Nutzen der Vielfalt. Universitätsbibliothek Kassel, Kassel, pp 31-35

Kooistra LI, Hessing WAM (1988) Ein frühmittelalterlicher Brunnen mit einer exotischen Frucht aus Houten. Berichten van de Rijksdienst voor het Oudheidkundig Bodemonerzoek 38:207-228

Kreuz A (1994) Bemerkungen zu archäobotanischen Untersuchungen im römischen vicus Hanau-Kesselstadt, Salisweg. Neues
Magazin für Hanauische Geschichte. Mitteilungen des Hanauischen Geschichtsvereins 1994:4-6

Kreuz A (1997) Genuss im Liegen oder fast food am Lagerfeuer? Kulinarische Möglichkeiten im römischen Hessen. In: Schallmayer E (ed) Hundert Jahre Saalburg. Vom römischen Grenzposten zum europäischen Museum. Philipp von Zabern, Mainz, pp 174-183

Lorey H, Reinhard U (2002) Der Flaschenkürbis - Gemüse des Jahres 2002. In: Hammer K, Gladis T, Hethke M (eds) Kürbis, Kiwano \& Co. - vom Nutzen der Vielfalt. Universitätsbibliothek Kassel, Kassel, pp 24-30

Lundström-Baudais K, Mignot C, Brunier C, Grudler A, Baudais D, Bidault M (1993) Le milieu végétal au XIe siècle: macrorestes et paléosemences. In: Colardelle M, Verdel E (eds) Les habitats du lac de Paladru (Isère) dans leur environnement. La formation d'un terroir au XIe siècle. Editions de la Maison des Sciences de l'Homme, Paris, pp 77-97

Marinval P (1992) Étude carpologique d'une structure exceptionelle: le silo du premier âge du fer de Thiais (Val-de-Marne). Acte XIII Coll. AFEAF:129-136

Marinval P, Pradat B (2004) Données remarquables sur l'économie végetale du début Second âge du Fer: le Grand-Jaunet à Liniez (Indre). In: Mazzochi G (ed) Approche archéologique de l'environnement et de l'aménagement du territoire ligérien. Féderation Archéologique du Loiret, Neuville-aux-Bois, pp 79-85

Morimoto Y, Maundu P, Fujimaki H, Morishima H (2005) Diversity of landraces of the white-flowered gourd (Lagenaria siceraria) and its wild relatives in Kenya: fruit and seed morphology. Gen Res Crop Evol 52:737-747

Paris H, Janick J (2008) What the Roman emperor Tiberius grew in his greenhouses. In: Pitrat M (ed) Cucurbitaceae 2008. INRA, Avignon, pp 33-41

Paris H, Daunay M-C, Pitrat M, Janick J (2006) First known image of Cucurbita in Europe, 1503-1508. Ann Bot 98:41-47

Paris H, Daunay M-C, Janick J (2009) The Cucurbitaceae and Solanaceae illustrated in medieval manuscripts known as the Tacuinum Sanitatis. Ann Bot 103:1,187-1205

Pollmann B, Jacomet S, Schlumbaum A (2005) Morphological and genetic studies of waterlogged Prunus species from the Roman vicus Tasgetium, Switzerland. J Archaeol Sci 32:1,471-1,480

Rackham H (ed, transl) (1950) Pliny, natural history, vol V. Harvard University Press, Cambridge, pp 460-469

Reddé M, Nuber HU, Jacomet S, Schibler J, Schucany C, Schwarz P-A, Seitz G (2005) Oedenburg. Une agglomération d'époque romaine sur le Rhin Supérieur. Fouilles francaises, allemandes et suisses sur les communes de Biesheim et Kunheim (Haut-Rhin). Gallia 62:215-277

Reimer PJ, Baillie MGL, Bard E, Bayliss A, Beck JW, Bertrand CJH (2004) IntCal04 terrestrial radiocarbon age calibration, 0-26 kyr BP. Radiocarbon 46:1,029-1058

Robinson RW, Decker-Walters DS (1997) Cucurbits. CAB International, New York

Rösch M (1995) Römische Brunnen in Lahr - Fundgruben für die Botanik. Archäol Ausgrab Bad-Württ 1994:151-156

Rösch M, Fischer E (2004) Aussergewöhnliche pflanzliche Funde aus Alamannengräbern des sechsten Jahrhunderts von Trossingen (Kreis Tuttlingen, Baden-Württemberg). Arch Korr 34:271-276

Rottoli M, Pessina A (2007) Neolithic agriculture in Italy: an update of archaeobotanical data with particular emphasis on northern settlements. In: Colledge S, Conolly J (eds) The origins and spread of domestic plants in southwest Asia and Europe. Left Coast Press, Walnut Creek, pp 140-154

Schlumbaum A, Tensen M, Jaenicke-Després V (2008) Ancient plant DNA in archaeobotany. Veget Hist Archaeobot 17:233-244

Schlumbaum A, van Glabeke S, Roldan-Ruiz I (2011) Towards the onset of fruit growing north of the Alps: ancient DNA from 
waterlogged apple (Malus sp.) seed fragments. Ann Anat. doi: 10.1016/j.aanat.2011.03.004

Shah BN, Seth AK, Dosai RV (2010) Phytopharmacological profile of Lagenaria siceraria. A review. Asian J Plant Sci 9:152-157

Terral J-F, Tabard E, Bouby L, Ivorra S, Pastor T, Figueiral I, Picq S, Chevance J-B, Jung C, Fabre L, Tardy C, Compan M, Bacilieri $\mathrm{R}$, Lacombe T, This $\mathrm{P}$ (2010) Evolution and history of grapevine (Vitis vinifera) under domestication: new morphometric perspectives to understand seed domestication syndrome and reveal origins of ancient European cultivars. Ann Bot 105:443-455

Thanheiser U (2002) Roman agriculture and gardening in Egypt as seen in Kellis. In: Hope CA, Bowen GE (eds) Dakleh Oasis project: preliminary reports on the 1994-1995 to 1998-1999 field seasons. Dakleh Oasis Project Monograph 11. Oxbow, Oxford, pp 299-310

Vandorpe P, Jacomet S (in press) Plant economy and environment. In: Reddé M (ed) Oedenburg. Les fouilles françaises, allemandes et suisses à Biesheim et Kunheim, Haut-Rhin, France, vol 2: L'agglomération civile. Monogr Röm-Germ Zentralmus Mainz, Mainz

Verbot-Bourrely A, Argant J, Bouby L, Latour-Argant C, Martin S (2010) Evolution d'un paysage de confluences de la Protohistoire à l'époque gallo-romaine : géomorphologie et paléoenvironnement du site Parc Saint-Georges à Lyon (69-France). Quarternaire 21:413-423

Wiethold J (1998) Recherches archéobotaniques en France du CentreEst. Centre archéologiques européen du Mont Beuvray. Rapport d'activité 1998:217-240

Yetisir H, Sakar M, Serce S (2008) Collection and morphological characterization of Lagenaria siceraria germplasm from the Mediterranean region of Turkey. Gen Res Crop Evol $55: 1,257-1,266$

Zama B (2000) Manufatti lignei del sito archeologico di via Vaspergolo - Corso Porta Reno (Ferrara - Nord Italia) datato $\mathrm{X}-\mathrm{XV}$ sec. d.C. Analisi xilologiche e considerazioni di ordine ethnobotanico e floristico-vegetazionale. Masters thesis, University of Bologna, Bologna

Zoro Bi IA, Koffi KK, Dje Y (2003) Caractérisation botanique et agronomique de trois espèces de cucurbites consommées en sauce en Afrique de l'Ouest : Citrullus sp., Cucumeropsis mannii Naudin et Lagenaria siceraria (Molina) Standl. Biotechnologie Agronomie Société et Environnement 7:189-199

Zwahlen R, mit Beiträgen von Frey-Kupper S, Gundbacher B, Hüster Plogmann H, Klee M, Schlumbaum A, Stopp B, Wick L, Zwahlen R et al (2007) Vicus Petinesca Vorderberg: Die Ziehbrunnen. Archäologischer Dienst Kanton Bern, Bern, p 214 